\title{
Reduksi Udema Kaki Mencit (Mus musculus) Terinduksi Karagenan Setelah Pemberian Ekstrak Daruju (Acanthus ilicifolius L.)
}

\section{Edema Reduction of Mices Feet (Mus musculus) Induced Carrageenan After Giving Daruju Extracts (Acanthus ilicifolius L.)}

\author{
Darul Ikhwan, Octavian Rachmadi, Annisa Dyah Astari Putri, Ari Widiyantoro* \\ Program Studi Kimia FMIPA Universitas Tanjungpura, Pontianak, Indonesia \\ *E-mail :ari.widiyantoro@chemistry.untan.ac.id
}

Received: 27 April 2020; Accepted: 24 Desember 2020; Published: 31 Desember 2020

\begin{abstract}
Abstrak
Acanthus ilicifolius L. merupakan salah satu tanaman mangrove yang banyak mengandung metabolit sekunder yang potensial sebagai bahan baku obat. Masyarakat Kabupaten Sambas Provinsi Kalimantan Barat menggunakan ekstrak daun daruju untuk mengatasi rasa nyeri pada pegal-pegal dan bengkak. Penelitian ini bertujuan untuk mengetahui aktivitas antiinflamasi ekstrak daun daruju berupa reduksi udema kaki mencit (Mus musculus) yang diinduksi karagenan setelah pemberian ekstrak daun daruju. Metode yang digunakan berupa ekstraksi secara maserasi dan partisi dilanjutkan dengan uji fitokimia dari ekstrak kasar dan fraksi-fraksi hasil partisi. Selanjutnya ekstrak kasar dan fraksi hasil partisi dilakukan uji reduksi udema terhadap kaki mencit yang diinduksi karagenan. Hasil penelitian menunjukkan bahwa fraksi etil asetat memiliki aktivitas antiinflamasi terbaik karena mampu menurunkan udema kaki mencit terinduksi karagenan sebesar $75 \%$ pada dosis $750 \mathrm{mg} / \mathrm{kg}$ BB. Fraksi etil asetat memiliki kemampuan mereduksi udema karena mengandung senyawa golongan flavonoid dan terpenoid.

Kata Kunci: Achantus ilicifolius L., udema, karagenan, antiinflamasi
\end{abstract}

\begin{abstract}
Acanthus ilicifolius L. is one of the mangrove plants that contain a lot of potential secondary metabolites of medicinal raw materials. People of Sambas Regency of West Kalimantan Province uses leaves extract daruju to overcome the pain in the stiff and swollen. The objective of this study was to know the antiinflammatory activity of leaves extract of daruju, in the form of edema reduction of mices feet induced carrageenan. The method used in the form of maceration and partition extraction followed by phytochemical test of crude extract and the fraction of result of partition. Furthermore, the crude extract and the fraction of the result of the partition were tested for the reduction of edema mices feet induced carrageenan. The results showed that ethyl acetate fraction had the best antiinflammatory activity because it was able to decrease the edema of mices feet by $75 \%$ at $750 \mathrm{mg} / \mathrm{kg} \mathrm{BW}$. Ethyl acetate fraction has the ability to reduce edema because it contains group compounds of flavonoid and terpenoid.
\end{abstract}

Keywords: Achantus ilicifolius L., Edema, Carrageenan, Antiinflamation

\section{PENDAHULUAN}

Masyarakat Kabupaten Sambas Provinsi Kalimantan Barat banyak menggunakan ekstrak daun daruju (Acanthus ilicifolius L.) untuk mengobati rasa nyeri pada kulit dan kaki yang bengkak. Menurut Amer et al.(2004) genus Acanthus mengandung senyawa golongan flavonoid, terpenoid dan alkaloid. Senyawa golongan flavonoid dan terpenoid ini mempunyai kadar paling banyak pada bagian daun tanaman daruju.
Sejauh ini bagian akar, batang, dan daun digunakan untuk mengobati penyakit kulit dan penyakit dalam yang dilakukan oleh masyarakat secara tradisional. Oleh karena itu banyak sekali penelitian yang mulai mengeksplorasi aktivitas biologik ekstrak daun, akar dan batang dari genus Acanthus untuk mengetahui kandungan senyawa dan aktivitas farmakologinya. Hal ini dilakukan agar dapat dikembangkan untuk peningkatan kesehatan masyarakat. 
Manfaat lain tanaman daruju secara literatur menunjukkan mampu mengobati luka terkena benda beracun, cacingan, bisul, sakit perut, asma, katarak, diabetes, rematik, wasir, radang gigi, migren, diabetes, hepatitis, HIV/AIDS dan herpes, serta dapat mengobati kanker. Kandungan senyawa metabolit sekunder selain flavonoid dan terpenoid adalah alkaloid, saponin dan steroid (Amer et al., 2004; Simplice et al., 2008; Andriani et al., 2020; Agoramoothy et al., 2008; Chakraborty et al., 2007, Avijit et al., 2012). Kandungan metabolit sekunder tersebut mampu memberikan aktivitas biologik dalam berbagai uji antioksidan, anti HIV dan antikanker.

Saranya et al., 2015 telah mereview beberapa aktivitas biologis yang ditunjukkan oleh semua bagian dari tumbuhan daruju. Daun daruju menunjukkan aktivitas sebagai antimikroba, hepatoprotektor dan antiinflamasi. Bagian akar menunjukkan aktivitas sebagai antioksidan sedangkan bagian bunga menunjukkan aktivitas sebagai antioksidan dan sitotoksik. Ekstrak metanol seluruh gabungan bagian tanaman daruju menunjukkan aktivitas antikanker leher rahim terhadap sel HeLa. Namun belum ada informasi ilmiah tentang aktivitas antiinflamasi ekstrak daruju yang mereduksi udema kaki mencit setelah pemberian karagenan terutama untuk ekstrak daun daruju yang tumbuh di kawasan pantai dan sungai sekitar tanah gambut di Kalimantan Barat. Kondisi geografis dan tanah akan mempengaruhi kadar metabolit sekunder dan aktivitas biologiknya. Berdasarkan uraian di atas maka penelitian ini bertujuan untuk mengetahui dosis ekstrak daruju yang mampu mereduksi udema kaki mencit yang diindukasi karagenan.

\section{METODE PENELITIAN}

\section{Ekstraksi dan Fraksinasi}

Sampel daun daruju diambil dari kawasan pantai sekitar Kabupaten Sambas Provinsi Kalimantan Barat, Indonesia. Sampel daun daruju sebanyak $5 \mathrm{~kg}$ basah dibersihkan lalu dikeringanginkan pada suhu kamar selama beberapa hari. Setelah kering dengan kadar air $<10 \%$ daun dipotong-potong lalu diblender dan diayak dengan ukuran 60 mesh. Serbuk daun daruju sebanyak $2 \mathrm{~kg}$ dimaserasi dengan metanol $80 \%$ (teknis yang telah diredistilasi) pada suhu kamar selama 24 jam. Ekstrak disaring dan filtratnya dikumpulkan. Residu dimaserasi kembali dengan cara menambahkan metanol yang baru (diulang sampai 3x24 jam sampai jernih). Seluruh filtrat dikumpulkan dan dipekatkan dengan evaporator, selanjutnya ditimbang untuk mengetahui rendemennya.

\section{Pemisahan}

Ekstrak metanol kental selanjutnya dilarutkan kembali dengan metanol untuk dilakukan pemisahan secara partisi dengan $n$-heksana, diklorometana dan etil asetat. Partisi dengan $n$-heksana dilakukan untuk memisahkan lemak dan berbagai metabolit sekunder yang bersifat nonpolar. Fraksi $n$-heksana, diklorometana, etil asetat dan metanol selanjutnya dipekatkan dengan evaporator. Selanjutnya masing-masing ekstrak kental hasil partisi dilakukan skrining fitokimia dan uji reduksi udema kaki mencit yang diinduksi karagenan dengan alat plestimometer.

\section{Uji Fitokimia}

Ekstrak metanol dan fraksi-fraksi hasil partisi dilakukan skrining metabolit sekunder. Uji dilakukan secara kromatografi lapis tipis dengan penampak noda untuk golongan fenolik, flavonoid, alkaloid, terpenoid dan steroid. Uji fitokimia dengan metode KLT dilakukan dengan cara mencari eluen yang terbaik yang dapat memisahkan senyawasenyawa dalam ekstrak uji. Pemisahan yang terbaik jika eluen tersebut mampu memunculkan jumlah spot yang banyak dan terpisah dengan baik antar spotnya. Eluen terbaik ini digunakan untuk uji fitokimia pada ekstrak pada semua golongan metabolit sekunder. Setelah itu setiap KLT disemprot dengan reagen uji fitokimia.

\section{Uji Reduksi Udema Kaki Mencit (Mus musculus) Setelah Induksi Karagenan}


Uji aktivitas antiinflamasi dilakukan berdasarkan pada kemampuan ekstrak mengurangi atau menekan derajat udema yang diinduksi pada hewan percobaan. Induksi udema dilakukan pada kaki mencit dengan cara penyuntikan suspensi karagenan intraplantar. Ekstrak/fraksi diberikan secara oral 1 jam sebelum penyuntikan karagenan. Ukuran udema kaki diukur dengan alat yang bekerja berdasarkan hukum Archimedes (pletismometer). Aktivitas antiinflamasi larutan uji ditunjukkan oleh kemampuannya mengurangi udema yang diinduksi pada kaki mencit..

Sebelum perlakuan mencit jantan yang akan dijadikan hewan coba dilakukan aklimatisasi terlebih dahulu selama 2 minggu dengan cara ditempatkan pada sebuah kandang kelompok berupa bak plastik. Selama diaklimatisasi mencit diberi makan berupa pellet dan minum ad libitum. Mencit jantan strain balbc umur 23 bulan dengan bobot badan berkisar antara 20-25 g, dikelompokkan dalam kelompokkelompok tertentu, masing-masing 5 ekor. Pada kelompok A merupakan kontrol positif (indometasin) dengan dosis $50 \mathrm{mg} / \mathrm{kg} \mathrm{BB}$, kelompok B, C dan D merupakan kelompokkelompok perlakuan dengan pemberian ekstrak hasil maserasi dan hasil partisi dengan dosis masing-masing $250 \mathrm{mg} / \mathrm{kg} \mathrm{BB}, 500$ $\mathrm{mg} / \mathrm{kg}$ BB dan $750 \mathrm{mg} / \mathrm{kg}$ BB. Diusahakan berat badan antar tikus tidak jauh berbeda. Volume telapak kaki kelompok kontrol dan kelompok uji dibandingkan secara statistik dengan uji t (taraf kepercayaan 95\%) sehingga dapat disimpulkan apakah perbedaan yang diperoleh bermakna. Jika bermakna dihitung rata-rata \% reduksi radang yang terjadi pada kelompok uji dengan rumus \% reduksi radang $=\{(a-b) / a\} \times 100 \%$. Dimana a dan b, berturutturut adalah volume rata-rata telapak kaki kelompok kontrol dan kelompok uji. Nilai \% reduksi radang ini menunjukkan kemampuan obat uji menekan radang (aktivitas antiinflamasi) dimana peradangan pada kelompok kontrol adalah 100\%. Dosis efektif dari obat uji adalah dosis obat uji yang memberikan reduksi radang sebesar $25 \%$ dari radang pada kelompok kontrol (Audina et al., 2018; Apridamayanti et al., 2018).

Ukuran radang pada masing-masing kaki mencit dapat pula dihitung terhadap bagian kaki lainnya dari mencit yang sama sebelum penyuntikan karagenan. Perbandingan persentase reduksi radang dilakukan antara kelompok kontrol dengan kelompok uji. Pembengkakan kaki tikus kontrol positip harus > $30 \%$ agar hasil dapat digunakan dengan baik.

\section{HASIL DAN PEMBAHASAN}

Berdasarkan hasil penelitian diperoleh sampel daun daruju basah mempunyai kadar air 53\% tetapi setelah dikeringkan menjadi $10 \%$ sehingga sampel mudah diserbukkan. Ekstraksi dengan maserasi menghasilkan rendemen ekstrak kasar metanol 15,11\%. Partisi ekstrak kental metanol menghasilkan fraksi metanol 20,15\%, fraksi etil asetat $45,67 \%$, fraksi diklorometana $20,10 \%$ dan fraksi $n$-heksana $13,07 \%$ serta sebagian kecil hilang dalam proses pemisahan. Ekstrak kental metanol dan fraksi hasil partisi selanjutnya dilakukan skrining fitokimia untuk mengetahui kandungan metabolit sekundernya secara kualitatif (Tabel 1).

Tabel 1. Hasil Skrining Fitokimia Ekstrak Metanol dan Fraksi-Fraksi Hasil Partisi Daun Daruju

\begin{tabular}{lccccc}
\hline \multicolumn{1}{c}{ Sampel } & Fen & Alk & Ter & Fla & Ste \\
\hline Ekstrak & + & + & + & + & + \\
Metanol & & & & & \\
Fraksi Metanol & + & + & - & + & - \\
Fraksi Etil & + & + & - & + & - \\
Asetat & & & & & \\
Fraksi & + & + & + & + & - \\
Diklorometana & & & & & \\
Fraksi $n$ - & - & - & + & - & + \\
Heksana & & & & & \\
\hline Keterangan & & & &
\end{tabular}

Keterangan : Fen (Fenolik), Alk (Alkaloid), Ter (Terpenoid), Fla (Flavonoid) dan Ste (Steroid). 


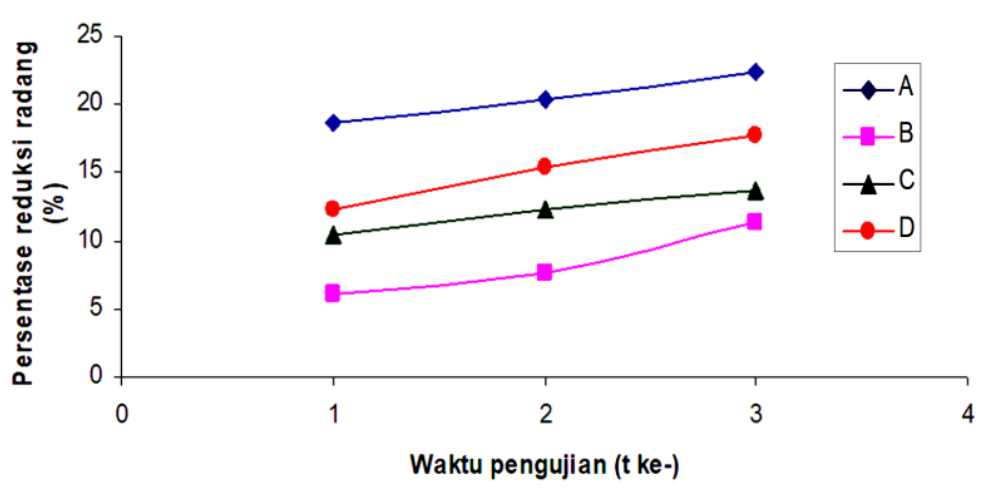

Gambar 1. Persentase reduksi radang kaki mencit setelah pemberian ekstrak metanol daruju

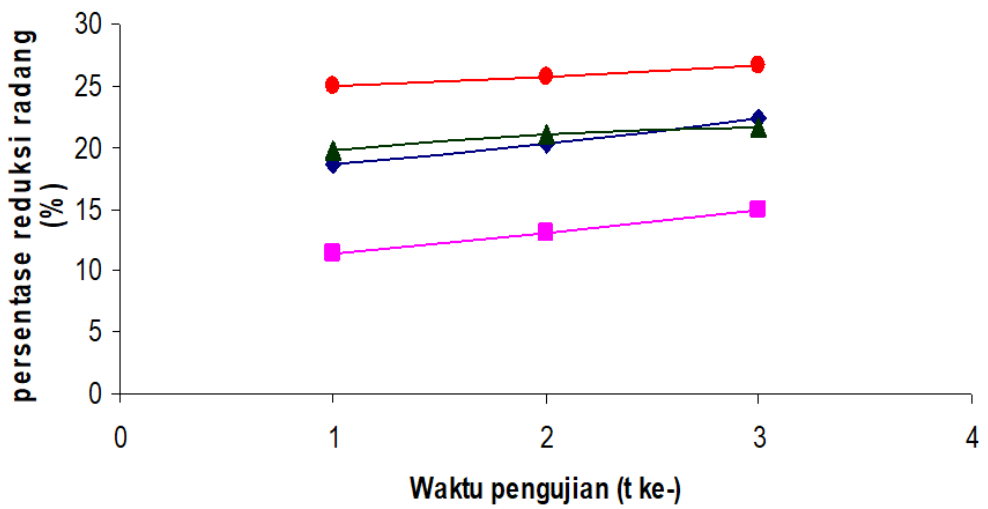

Gambar 2. Persentasi reduksi radang kaki mencit setelah pemberian fraksi etil asetat daruju

Skrining fitokimia dilakukan dengan metode KLT. Hal ini untuk mengetahui distribusi golongan-golongan metabolit sekundernya melalui spot-spot KLT. Berdasarkan Tabel 1 terlihat bahwa golongan metabolit sekunder fenolik, flavonoid dan alkaloid terdistribusi pada fraksi semipolar dan polar sedangkan golongan metabolit sekunder terpenoid dan steroid terdistribusi pada fraksi semipolar dan nonpolar.

Untuk mengetahui aktivitas antiinflamasi ekstrak/fraksi daun daruju maka dilakukan uji reduksi udema terhadap kaki mencit yang diinduksi karagenan. Pengujian dilakukan pada jam ke-1, ke-4 dan ke-10 setelah pemberian ekstrak/fraksi. Pengujian dilakukan pada ekstrak metanol dan seluruh fraksi hasil partisi. Berdasarkan hasil penelitian terlihat bahwa ekstrak metanol dan fraksi etil asetat menunjukkan aktivitas reduksi udema yang bagus. Hasil uji reduksi udema kaki mencit setelah pemberian ekstrak metanol dan fraksi etil asetat ditampilkan pada Gambar 1 dan 2.

Berdasarkan Gambar 1 terlihat bahwa ekstrak metanol daun daruju dalam berbagai dosis yaitu variasi dosis (B) $250 \mathrm{mg} / \mathrm{kg} \mathrm{BB}$, (C) $500 \mathrm{mg} / \mathrm{kg} \mathrm{BB}$ dan (D) $750 \mathrm{mg} / \mathrm{kg} \mathrm{BB}$ dengan senyawa pembanding indometasin dengan dosis (A) $50 \mathrm{mg} / \mathrm{kg}$ BB mampu mereduksi udema kaki mencit yang diinduksi karagenan. Ekstrak metanol daun daruju yang mengandung metabolit sekunder golongan fenolik, alkaloid, flavonoid, terpenoid dan steroid (sesuai Tabel 1) menunjukkan aktivitas reduksi udema yang baik tetapi masih lebih rendah dari persentase kontrol positif.

Pada fraksi etil asetat dilakukan uji pada variasi dosis (B) $250 \mathrm{mg} / \mathrm{kg} \mathrm{BB}$, (C) 500 $\mathrm{mg} / \mathrm{kg} \mathrm{BB}$ dan (D) $750 \mathrm{mg} / \mathrm{kg}$ BB dengan senyawa pembanding indometasin dengan dosis (A) $50 \mathrm{mg} / \mathrm{kg} \mathrm{BB}$. Berdasarkan gambar 
diketahui bahwa fraksi etil asetat mempunyai aktivitas antiinflamasi (mereduksi udema kaki mencit yang diinduksi karagenan) paling bagus diantara ekstrak kental metanol dan fraksi hasil partisi lainnya.. Berdasarkan Gambar 2 terlihat bahwa dosis (D) $750 \mathrm{mg} / \mathrm{kg}$ BB fraksi etil asetat mempunyai persentase reduksi lebih tinggi dari kontrol positif. Efek antiinflamasi ini masih tergantung dosis (Dewi et al., 2015). Hal ini terkait dengan kandungan senyawa metabolit sekunder yang terkandung didalamnya yaitu flavonoid dan terpenoid (Khotimah \& Muhtadi, 2016). Efek antiinflamasi flavonoid didukung oleh aksinya sebagai antihistamin. Flavonoid dapat menghambat pelepasan histamin dari sel mast. Flavonoid dapat menghambat enzim c-AMP fosfodiesterase sehingga kadar cAMP dalam sel mast meningkat, dengan demikian kalsium dicegah masuk ke dalam sel yang berarti juga mencegah pelepasan histamine (Khotimah \& Muhtadi, 2016; Santi, 2015). Selain itu, mekanisme flavonoid dalam menghambat terjadinya radang melalui dua cara yaitu menghambat asam arakidonat dan sekresi enzim lisosom dan endothelial. Terhambatnya pelepasan asam arakidonat dari sel inflamasi akan menyebabkan kurang tersedianya subtrat arakidonat bagi jalur siklooksigenase dan jalur lipooksigenase (Audina et al., 2018; Andayani et al., 2018; Anggraeny et al., 2016)
Mekanisme kerja golongan senyawa flavonoid dan terpenoid mengikuti mekanisme obat antiinflamasi nonsteroid. Fraksi etil asetat memberikan kemampuan reduksi $75 \%$ pada dosis $750 \mathrm{mg} / \mathrm{kg}$ BB. Aktivitas antiinflamasi pada ekstrak metanol lebih rendah dibandingkan aktivitas antiinflamasi fraksi-fraksi hasil partisi, hal ini karena efek antagonis. Mekanisme kerja antiinflamasi golongan steroid tidak bisa bekerja secara bersama dengan golongan nonsteroid.

Kandungan metabolit sekunder pada masing-masing fraksi dan ekstrak akan mempengaruhi aktivitas biologik dari fraksi atau ekstrak tersebut. Kadar metabolit sekunder dari setiap tanaman akan berbeda tergantung berbagai faktor seperti faktor geografis, kondisi tanah, perlakuan saat tanam dan proses pascapanen.

\section{KESIMPULAN}

Berdasarkan hasil penelitian dapat disimpulkan bahwa fraksi etil asetat daun daruju dosis $750 \mathrm{mg} / \mathrm{kg} \mathrm{BB}$ mampu mereduksi udema kaki mencit (Mus musculus) yang diinduksi karagenan secara lebih baik dibandingkan ekstrak kasar dan fraksi hasil partisi lainnya. Kandungan senyawa yang diduga memberikan aktivitas antiinflamasi adalah golongan flavonoid dan terpenoid.

\section{Daftar Pustaka}

Agoramoorthy, G., Chen F.A., Venkatesalu, V., 2008, Evaluation of antioxidant polyphenols from selected mangrove plants of India, Asian J. Chem 2, 1311-1322

Amer, M.E., Shoer, M.I.A., Kader, M.S., 2004., Alkaloids and flavone acyl glycosides from Acanthus arboreus, J. Braz. Chem. Soc. 15, 262-266

Andayani, D., Suprihartini, E., Astuti, M. 2018. Efek Antiinflmasi Ekstrak Etanol Krokot (Portulaca oleracea L.) pada Udema Tikus yang Diinduksi Karagenin, J.Pharm. Sci. Clin. Res., 1, 43-49

Andriani, D., Revianti, S., Prananingrum, W. 2020. Identification of Compounds Isolated from Methanol Extract of Acanthus ilicifolius Leaves and Evaluation of Their Antifungal and Antioxidant Activity, Biodiversitas, 21(6), 2521-2525 
Anggraeny, E.N.,Pramitaningastuti, A.S., 2016. Studi Uji Daya Antiinflamasi dan Antipiretik Ekstrak Etanol Daun Lengkeng (Dimocarpus longan Lour) pada Tikus Jantan (Rattus norvegicus) Galur Wistar, Jurnal Ilmiah Farmasi, 2 (2), 44-51

Apridamayanti, P., Sanera, F., Robiyanto, R.2018. Aktivitas Antiinflamasi Ekstrak Etanol Daun Karas (Aquilaria malaccensis Lamk), Pharm.Sci.Res. 5(3), 152-158

Audina, M., Yuliet, Kaherati, K., 2018. Efektivitas Antiinflamasi Ekstrak Etanol Daun Sumambu (Hyptis capitata Jacq.) pada Tikus Jantan (Rattus norvegicus L.) yang Diinduksi Karagenan, Biocelebes, 12 (2), 17-23

Avijit, D., Sarkar, R., Howlader, S.I., Hamiduzzaman, Hossain, M.A., 2012, Phytochemical screening and evaluation of antioxidant, cytotoxic and antimicrobial properties of Acanthus ilicifolius (Acantaceae), Inter. Res. J. Pharm., 3 (8), 153-156

Chakraborty, T., Bhuniya, D., Chatterjee, M., Rahaman, M., Singha, D., 2007, Acanthus ilicifolius plant extract prevents DNA alterartions in a transplantable Ehrlich ascites carcinoma-bearing murine model, World J. Gastroenterology, 48, 6538-6548

Dewi, A.A.A.T.S., Puspawati, N.M. Suarya, P. 2015. Aktivitas Antiinflamasi Ekstrak Eter Kulit Batang Tenggulun (Protium javanicum Burm) Terhadap Edema pada Tikus Wistar yang Diinduksi dengan Karagenan, Jurnal Kimia, 9 (1), 13-19

Khotimah, S.N., Muhatdi, A., 2016. Review Artikel, Beberapa Tumbuhan yang Mengandung Senyawa Aktif Antiinflamasi, Farmaka, 14 (2), 28-40

Santi, T.D., 2015. Uji Toksisitas Akut dan Efek Antiinflamasi Ekstrak Metanol dan Ekstrak nHeksana Daun Pepaya (Carica papaya L.), Pharm. Sci. Res., 2 (2), 101-114

Saranya, A., Ramanathan T., Selvarajan, K., Kasavanarayanan, Adam A., 2015, Traditional Medicinal uses, chemical constituents, and Biological activties of Mangrove Plant, Acanthus ilicifolius , a brief review, American-Eurasian, J. Agric. Environment., Sci., 15 (2), 243-250

Simplice, F.H., Paulin, N., Elvis, C., Acha, A.E. 2008., Protective effect of Acanthus montanus in carrageenan-induced models of local inflammation, inhibitory effect on nitric oxide (NO) production, Pharmacologyonline 2, 161-169. 